\title{
Influence of the Work-Family Relationship on Perceived Health 5-Years Later: The Moderating Role of Job Insecurity
}

\author{
Rita Bandeira ${ }^{1} \cdot$ Maria José Chambel $^{1} \cdot$ Vânia Sofia Carvalho $^{1}$ (D)
}

Accepted: 3 October 2020 / Published online: 13 October 2020

(c) Springer Nature B.V. 2020

\begin{abstract}
Previous studies on the work-family relationship have analyzed the influence of work-family conflict and work-family enrichment on an individuals' lives, namely on their well-being and health. Besides, attempts have been made to analyze the influence of other aspects of the labor context on this relationship, such as job insecurity. However, few have analyzed this relationship and interaction from a longitudinal perspective. Thus, the main purpose of this study is to analyze the moderating role of job insecurity in the work-family relationship and the perceived health of 373 workers of a Portuguese bank, across time. The results showed a negative influence of work-family conflict on perceived health 5 years after. Also, job insecurity was found to offset the relationship between work-family enrichment and perceived health, acting as a buffer. This research allows for a better understanding of how job insecurity, a characteristic of modern-day employment, can impact workers' quality of life. This paper also refers to some practical implications, in addition to the limitations of the study, and presents suggestions for future research in this context.
\end{abstract}

Keywords Work-family conflict · Work-family enrichment $\cdot$ Job insecurity $\cdot$ Health perceptions

\section{Introduction}

Fostering a balance in the professional and family lives of individuals through the reduction of psychosocial stressors in the workplace (WHO 2015) is one of the principal social challenges of the twenty-first century. The main problems reported by workers are related to excessive working hours or over-fatigue caused by their professional activity. This compromises individuals' performance of the family role, and they frequently refer to having difficulty in enjoying moments of their personal life due to work-related issues (Eurofound and the International Labour Office 2017). One of the occupational sectors that have been highlighted due to its critical stress levels is the banking workplace where empirical

Maria José Chambel

mjchambel@psicologia.ulisboa.pt

1 Faculdade de Psicologia, Universidade de Lisboa, Alameda da Universidade, 1640-013 Lisbon, Portugal 
research has shown the deleterious psychological effects on employees, specifically on their physical health (Giorgi et al. 2017).

Hence, this study seeks to focus on the work-family relationship of bank employees and on how it can influence their perceived health. Perceived health is an important well-being indicator (Diener et al. 2013; Ware et al. 1978) correspond to an overall assessment, not focused on specific health components (i.e., mental health, physical health, and physiological health). Resulting from changing work and family patterns, this theme continues to be the target of research at an international level, with emphasis on an analysis of work-family conflict and work-family enrichment. Work-family conflict (WFC) refers to an inter-role conflict where the demands of the professional role are incompatible with the demands of the family role (Greenhaus and Beutell 1985). Work-family enrichment (WFE) presents a positive perspective of the work-family relationship and refers to the extent to which experiences in one role improve the quality of life in the other (Greenhaus and Powell 2006, p. 72). Research has shown that the interaction between the work-family domains, whether in the form of conflict, considered a stressor, or enrichment, considered a facilitator, has an impact on individuals' health (Frone et al. 1997) and well-being (Allen et al. 2000; Carvalho and Chambel 2014a). Particularly, within the banking sector, studies emphasized that stress at work in bank employees gives rise to WFC (Mughal et al. 2010; Kan and Yu 2016) and that WFE provides better health perceptions (Carvalho and Chambel 2014a). However, to the best of our knowledge, no study with bank employees has analyzed how WFC and WFE simultaneously can influence employees' perceived health. Thus, the first goal of our study is to analyze these relationships.

In addition to WFC, insecurity is another stressor in the current employment paradigm. Insecurity refers to the perceived powerlessness to maintain the desired continuity in a threatened job situation (Greenhalgh and Rosenblatt 1984). The economic crisis, experienced at a global level, in 2008 and, more recently, the COVID-19 crises where employers have turned to furloughing or laying off employees to stay afloat, has given rise to general instability in job security (Ellonen and Nätti 2015; Kuroki 2015; Rudolph et al. 2020). During and following periods of crisis, many businesses are forced to make adjustments and implement strategic changes, which may include internal restructuring, resulting in downsizings or collective redundancies, considered to be adaptive strategies in the face of an increasingly more competitive and globalized labor market (Ferrie et al. 2008). These changes lead to workers experiencing increased job insecurity, which may directly or indirectly affect their levels of well-being and perceived health (Snorradóttir et al. 2015). Thus, job insecurity acts as a demand or stressor of the workplace, which may bring health decrease (Cheng and Chan 2008; De Witte 2005; De Witte et al. 2016; Shoss 2017; Sverke et al. 2002). In light of the Stress Process Model (Pearlin and Bierman 2013), stressors are considered to be able to interact with each other, entailing worse consequences for individuals. Thus, interaction among these stressors, WFC, and job insecurity may entail significant consequences for workers' health. Based on this, it is also our aim to explore the role of job insecurity in the relationship between WFC and perceived health. The study of Minnotte and Yucel (2018) analyzed these relationships, and that of $\mathrm{Hu}$ et al. (2018) analyzed how job insecurity of a qualitative nature, which refers to the loss of job characteristics (rather than actual job loss, which refers to job insecurity of a quantitative nature), through WFC affects well-being. It is the aim of this study to take the level of analysis even further, by overcoming some of the limitations presented in the aforementioned study of Minnotte and Yucel (2018), namely the cross-sectorial nature of the study and the variables measurement reliability. Firstly, a longitudinal study was developed with two time-points, separated by a 5-year interval, enabling the influence of the work-family relationship to 
be observed over time. Secondly, to overcome measurement error issues declared by Minnotte and Yucel's (2018) our study used reliable scales previously used with bank employees (detailed in the method section). Further, considering that the work-family relationship has both positive and negative aspects, not only was the WFC included, but also the WFE. Specifically, WFE is viewed as a resource that results in positive outcomes (i.e. perceived health, Carvalho and Chambel 2014a). However, the presence of a threat, such as job insecurity, may weaken this gain process (Hobfoll 2002). In this line, the final aim of this research is to examine the moderating role of job insecurity in the relationship between WFE and perceived health over time.

This study was conducted using data collected from one of the six major private portuguese banks. Therefore, it is important to contextualize the Portuguese scenario. In recent years, European labor markets have been experienced major pressures, with a magnitude in economic and social transformations (i.e. changes on the employment relationship and the high and persistent levels of unemployment) that impact the social protection systems (Valadas 2011). While some countries seem to address the new challenges without fail, in Portugal, the social protection structures continue to be insufficiently prepared to respond, for instance, to less secure jobs and growing unemployment. Portugal is considered a vulnerable country comprised not only a negative macroeconomic scenario but also additional risks of low paid and precarious forms of employment (Ferrera et al. 2000; Valadas 2011). Social phenomena, such as unemployment, the precariousness of work, and the intensification of the labor rhythm affects particularly the bank sector (Hantzaroula 2015). Within the scenario of the global economy and unregulated markets led to a series of changes in the way finances services work and are sold that have consequences to the organizations and execution of work in the bank sector (Giorgi et al. 2017). For instance, exists an intensification of outsourcing and flexibility of work, a redefinition of tasks and traditional banking activities and employees are pressed to charging clients for a greater diversity of services and products and transferring more and more services to the clients themselves (Giorgi et al. 2017; Silva and Navarro 2012). Furthermore, as a result of the recent economic crisis, this sector has undergone structural changes, such as downsizings and the closure of branches and a considerable reduction in job positions intensified the volume of work for those who remained (Silva and Navarro 2012). In fact, over a period of 3 years, in the bank where this study was conducted, almost 1500 employees were dismissed and around 200 branches were closed, giving rise to a reduction of approximately $30 \%$ of the workforce (This data presented was provided by the Human Resource Department of the bank). Further restructuring is also foreseen, which will involve the reduction of another 500 employees by 2021. As such, studying how job insecurity may influence the levels of the perceived health of these workers in their relationship with the work-family domain is of unquestionable interest and relevance. In line with other institutions in the sector, the sample in question also underwent a restructuring and reform process, resulting in a loss of the organization's essential character and dismissals.

\section{Theoretical Framework}

\subsection{The Work-Family Relationship and Perceived Health}

According to the scarcity of resources hypothesis (Goode 1960), WFC causes individuals to perceive that investment in a certain context or role depletes resources such as time, 
energy, and attention, thus leading them to invest in another role in which these resources are understood as being finite. Furthermore, according to the Role Theory (Goode 1960), the multiplicity of roles and their demands make it difficult to perform well in the roles adopted, thus triggering conflict. Therefore, WFC is negatively related to workers' wellbeing in so far as a prolonged response to a stressor may give rise to health deterioration (Hakanen and Schaufeli 2012; Schaufeli and Bakker 2004). Frone (2000) demonstrated that individuals reporting WFC were 3.13 times more likely to have a mood disorder, 2.46 times more likely to suffer from anxiety, and 1.99 times more likely to have a substance dependency than individuals who did not deal with this mismatch of roles. Physical health is also compromised by WFC, which may be a predictor of hypertension and heart conditions (Frone et al. 1996, 1997).

However, from a positive perspective, according to the WFE model, the performance of multiple roles can provide resources (e.g., skills and perspectives, respect for individual differences, development of relationships, flexibility) that help individuals to deal with the demands associated with the performance of other roles, thus acting as a facilitator (Greenhaus and Powell 2006; Geurts and Demerouti 2003). Therefore, WFE has proven to be beneficial for well-being, particularly for perceived health (Hakanen and Schaufeli 2012). Studies have shown that WFE has a positive impact on mental health (Grzywacz and Bass 2003), physical health (Grzywacz 2000), stress reduction (Grzywacz et al. 2002) and sleep quality levels (Williams et al. 2006).

Perceived health is one of the variables that enable an understanding of well-being. It is a subjective construct based on the experience of each individual, which can be assessed through self-rated health measures (Wikman et al. 2005). The importance of studying health in this context is related to the fact that the definition of health by the World Health Organization [WHO] (2015) encompasses the dimensions of social and mental well-being and is not restricted solely to the absence of disease or illness.

H1 WFC negatively influences the perceived health of workers in the banking sector.

H2 WFE positively influences the perceived health of workers in the banking sector.

\section{The Moderating Role of Job Insecurity}

As it implies the perceived possibility of job loss, job insecurity represents the threat of current job discontinuity (Probst 2003) and uncertainty regarding the future (Greenhalgh and Rosenblatt 1984; Shoss 2017), thus affecting individuals' well-being. In the current labor paradigm, job insecurity, coupled with unemployment and precarious work, largely determines the health of individuals (Pförtner 2017). Job insecurity differs from job loss in so far as it is experienced subjectively and may extend over a long period (Burgard et al. 2009), unlike actual job loss, which is immediate (Sverke et al. 2002). Having been identified as a psychosocial characteristic of work (Karasek et al. 1998), job insecurity acts as an occupational stressor, since it is characterized by feelings of helplessness and lack of control and is thus associated with lower well-being (De Witte 1999). Contrary to what would be expected, the impact of the threat of unemployment in terms of physical and mental health is similar to the impact of actual unemployment (Broom et al. 2006). Individuals who are involved in a restructuring process in their workplace, such as downsizings, may experience job insecurity since they are aware of 
what is happening and have observed the dismissal of their colleagues. Thus, the feeling of uncertainty concerning the future within the context of their job is increased. According to the literature, individuals who are not dismissed in a collective dismissal situation, referred to as "survivors" (Armstrong-Stassen 1994; Korkeamäki and Kyyrä 2014), develop feelings of insecurity regarding the future (Greenhalgh and Rosenblatt 2010), and their well-being is negatively impacted (Bamberger et al. 2012; Broom et al. 2006; Burchell 2011; Ferrie et al. 2008; Glavin 2015; Snorradóttir et al. 2015). Job insecurity can affect individuals in a variety of ways and manifests itself as a threat to financial stability and security and also decreases individuals' availability and participation in family life (Voydanoff 2004). Insecurity has been analyzed in the work-family relationship field of study and has been found to indirectly affect workers' personal life, through the negative spillover process, whereby it surpasses the work barrier and impacts on their personal and family domains (Bakker et al. 2009; Edwards and Rothbard 2000; Handaja and De Witte 2007). Although there is a direct causal effect between job insecurity and levels of health, insecurity can interact with the work-family relationship and change its influence on levels of health (Minnotte and Yucel 2018). Since WFC translates into the inability to balance the demands and resources of the work and family domains, in line with the Resource Conservation Theory (Hobfoll and Shirom 2001), it is believed that when individuals are confronted with demands and threats of a loss of resources, they become more vulnerable to the loss of other resources that could be valuable for other demands. Therefore, when faced with a situation of employment insecurity, individuals may need to invest more resources in the work domain and, for this reason, experience fewer resources, such as time and energy, for the family domain (Greenhaus and Beutell 1985). As it is characterized by uncertainty, job insecurity may also generate several uncertainties regarding aspects of employability, such as financial stability, which, in turn, may give rise to concerns in terms of the family's livelihood (Höge et al. 2015). Thus, using a sample of 2600 American workers, Minnotte and Yucel (2018) showed how workers with higher levels of WFC reported poorer levels of mental and physical health, and these effects were stronger when they also reported job insecurity.

Additionally, taking the assumptions of the Resource Conservation Theory (Hobfoll and Shirom 2001) into account, this study advances that the moderating effect of job insecurity may also act in the relationship between WFE and workers' health. Since job insecurity represents a resource loss threat, and in line with the primacy of resource loss (Hobfoll and Shirom 2001) assumption, one may expect a resource gain situation (such as that represented by WFE) to be less relevant in explaining the perceived health of workers. WFE may occur by instrumental or affective means (Greenhaus and Powell 2006). The instrumental route comprises a direct application of the resources acquired at work (for example, skills such as communication) while the affective route occurs when a resource acquired in one context (e.g. work) promotes positive affect in the other context (e.g. family), thus generating enrichment. In effect, exposure to a high impact stressor representing a resource loss threat, such as job insecurity, may prevent a resource gain and the potential positive effect felt by such gain. In such cases, WFE ceases to influence levels of well-being (Demerouti et al. 2001).

Thus, to contribute to the research in this area, and based on the notion that WFC and WFE present respective demands and resources in the lives of workers, job insecurity, as a moderator, is expected to have a significant influence on the relationship between conflict and enrichment among work-family and health in the banking population, after 5 years. Thus, the following hypotheses were formulated: 
H3 The negative influence of WFC on the perceived health of workers in the banking sector is moderated by job insecurity, after 5 years, to such an extent that this relationship is significantly stronger in situations characterized by high insecurity when compared to those with low levels of insecurity.

H4 The positive influence of WFE on the perceived health of workers in the banking sector is moderated by job insecurity, after 5 years, to such an extent that this relationship is significantly weaker in situations characterized by high insecurity when compared to those with low levels of insecurity.

\section{Method}

\subsection{Procedure and Sample}

A total of 1885 workers (48.04\% of the bank population) responded to the questionnaire at time 1 (T1). At time 2 (T2), 2197 workers (79\% of the bank population) participated in the study. The final sample consisted of workers who participated at both time-points of the study (2012 and 2017). Participation in the study was voluntary and confidential. The respondents completed an online questionnaire. At T1, the participants were asked to generate a personal code that could be remembered at $\mathrm{T} 2$ of the data collection, to enable us to correspond with the participants. In total, a correspondence of 373 codes was obtained, corresponding to the sample of this study. The current sample consists mainly of male individuals (55.2\%), corresponding to 206 participants. Regarding age at the time of data collection at T2, $42.9 \%$ of the employees were aged between 46 and 55 years, representing 160 of the participants, $38.3 \%$ between 36 and 45 years, $11.3 \%$ between 26 and 35 years and $7.5 \%$ were over the age of 55 years. Although the marital status and parenthood of employees were not investigated, so as not to compromise their anonymity, it may be assumed that since the vast majority of employees $(88.7 \%)$ were over the age of 36 years, at this stage in their life cycle one would expect them to have some type of role at the family level, be it in terms of marital status and/or parenthood. Considering seniority in the company, at T2, 42.1\% had been employed in the banking sector for between 20 and 30 years. Therefore, since traditional career models are grounded in a long-term relationship between the individual and one or two companies over the individual's working life (Lochab and Mor 2013), it is fair to assume that careers are still traditionally constructed in this sector. $39.7 \%$ of the participants had worked in the banking sector for between 10 and 20 years, $12.6 \%$ for at least 5 years, and $5.6 \%$ for over 30 years, thus pointing to a relatively low turnover rate. Dropout analyses revealed no significant differences at T1 among any of the study variables between those who dropped out and those who did not.

Measures.

\subsection{Work-Family Conflict}

This variable was measured using a total of fourteen items, based on the measurement instrument of Carlson et al. (2000), validated for the Portuguese population (Vieira et al. 2014) and also used in previous studies with portuguese population (Carvalho et al. 2018; Neto et al 2016a, b). Examples of items are: The demands of my job make it difficult to maintain the kind of relationship I would like to have with my husband/wife and/or my 
children and My job negatively interferes with my family tasks. Participants were asked to rate each item on a five-point Likert scale ( $1=$ Hardly ever to $5=$ Almost always $)$, and the scale had an internal consistency score of 0.92 for $\mathrm{T} 1$ and 0.93 for $\mathrm{T} 2$ of the study.

\subsection{Work-Family Enrichment}

Using a total of nine items of the instrument of Carlson et al. (2006), which was previously validated for the Portuguese population (Vieira et al. 2014) also used in previous studies with portuguese population (Carvalho and Chambel 2014a, b; 2016), participants were asked to rate each item on a five-point Likert scale $(1=$ Strongly disagree to $5=$ Strongly agree). Examples of items are: My engagement with my work helps me gain knowledge, and this helps me to be a better member of my family and My engagement with my work puts me in a good mood and this helps me to be a better member of my family. This scale had an internal consistency score of 0.94 for T1 and of 0.96 for T2 of the study.

\subsection{Perceived Health}

The scale of Ware et al. (1978) was used, which had also been previously used for the Portuguese population (Carvalho and Chambel 2014a, 2016; Neto 1992). The Perceived Health scale consists of four items, examples of which are: I feel better than ever and My health is excellent, assessed using a five-point Likert scale $(1=$ false to $5=$ true $)$, and presenting an internal consistency score of 0.91 for T1, and 0.90 for T2 of the study.

\subsection{Job Insecurity}

This variable was applied based on an adaptation of the scale of De Witte (2000), previously applied in a study in Portugal (Chambel and Fontinha 2009), using two items: I feel insecure about my future in this job and I feel that I may lose this job soon, assessed using a five-point Likert scale $(1=$ Strongly disagree to $5=$ Strongly agree $)$. This variable presented an internal consistency score of 0.78 for $\mathrm{T} 2$ of the study since it was not used at $\mathrm{T} 1$.

\subsection{Gender}

Prior research in the field of the work-family relationship (Batt and Valcour 2003) and job insecurity (Gaunt and Benjamin 2007) concedes that there may be differences depending on the gender of the participants. Thus, although not considered in the formulation of the hypotheses, the effect of gender was controlled so that the results would not be biased. The gender variable was assessed as a dummy variable (females $=0$; males $=1$ ).

\section{Data Analysis}

Using MPLUS V7, we began by verifying the adequacy of the measurement models underlying the responses to our various instruments, and their longitudinal measurement invariance across time points (Millsap 2011). Follow Hu and Bentler (1995) recommendations we presented the well-known global fit statistics for structural equation modeling methods were used: comparative fit index (CFI; satisfactory values of 0.90 and above), 
Tucker-Lewis index (TLI; satisfactory values of 0.90 and above), and root mean squared error of approximation (RMSEA; a satisfactory value below 0.08; Van de Schoot et al. 2012). We then computed the mean scores of the studied variables to inspect the evolution of each of the analyzed constructs over time. We assessed the evolution of each of the analyzed constructs based on paired sample $t$-tests, which allowed us to observe mean level changes between T1 and T2 for the studied variables. Furthermore, correlational analyses were conducted to obtain a preliminary idea about the relationships among the variables. These first analyses were computed with the SPSS 22.0 program. To directly test our proposed model, a regression-based path analysis was used with the support of PROCESS software, which is a computational tool for estimating and probing interactions and the direct effects of moderated models (Hayes 2012). More specifically, MODEL 1 was used, and to analyze the longitudinal effect on perceived health, this variable was introduced as a control variable at $\mathrm{T} 1$.

\section{Results}

\subsection{Confirmatory Factor Analysis}

To ensure that the measurement model operated in the same manner across the two time points, we perform sequential tests of measurement invariance (Millsap 2011). Specifically, we assessed (1) configural invariance, (2) weak invariance (loadings), (3) scalar invariance (thresholds). Fit statistics for the scalar model were: $\chi 2(1471)=3305.35, p<0.01$; RMSEA $=0.06, \mathrm{CFI}=0.91$, TLI $=0.90$ ).

\section{Descriptive Statistics and Correlations}

Table 1 shows the Mean (M) and Standard Deviation (SD) of the variables in the study sample at both points in time (T1 and T2), and although job insecurity was only verified at T2 of the study, this variable was analyzed with the variables of both points in time. Overall, a pattern of correlations at both points in time of the study may be observed. The

Table 1 Means, standard deviations and correlation coefficients between variables

\begin{tabular}{|c|c|c|c|c|c|c|c|c|c|}
\hline & \multirow[t]{2}{*}{ M } & \multirow[t]{2}{*}{ SD } & \multicolumn{7}{|l|}{$R$} \\
\hline & & & 1 & 2 & 3 & 4 & 5 & 6 & 7 \\
\hline 1. Gender ${ }^{\mathrm{a}}$ & - & - & & & & & & & \\
\hline 2. WFC T1 & 2.73 & .76 & -.04 & & & & & & \\
\hline 3. WFE T1 & 3.30 & .74 & .05 & $-.44 * *$ & & & & & \\
\hline 4. Health P. T1 & 3.48 & .83 & -.03 & $-.37 * *$ & $-.37 * *$ & & & & \\
\hline 6. WFC T2 & 2.85 & .82 & .00 & $.47 * *$ & $.13^{*}$ & $-.18^{* *}$ & & & \\
\hline 7. WFE T2 & 4.19 & 1.33 & .08 & $-.15^{* *}$ & $.31 * *$ & .03 & $-.40 * *$ & & \\
\hline 9. Health P. T2 & 3.23 & .80 & .02 & $-.23 * *$ & $.18 * *$ & $.37 * *$ & $-.36 * *$ & & $.25 * *$ \\
\hline 10. Insecurity & 3.43 & .92 & .08 & $.17 * *$ & $-.13^{*}$ & -.06 & $.27 * *$ & & $-.29 * *-.10 *$ \\
\hline
\end{tabular}

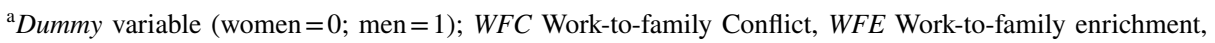
Health P. Health Perceptions; $* p<.05$ (2-tailed), ** $p<.01$ (2-tailed) 
control variable - gender-is also observed to have no significant relationship with any of the variables under study.

WFC is found to be significantly higher at T2 (t [372] $=-2.95, p=0.00)$, as is WFE ( $\mathrm{t}$ $[372]=-13.22, p=0.00)$. As for perceived health ( $\mathrm{t}[372]=5.46, p=0.00)$, it is observed to be significantly higher at $\mathrm{T} 1$.

\section{Hypothesis Testing}

The first hypothesis of this study assumed a direct and negative effect between the WFC and the perceived health of the study population. By analyzing Table 2, one may observe that the WFC of T1 is significantly and negatively related to perceived health at T2 $(b=-0.10, p=0.05)$. However, contrary to expectations, WFE at T1 does not have a significant relationship with perceived health at $\mathrm{T} 2(\mathrm{~b}=0.06, p=0.33)$. These results indicate that WFC at T1 explains perceived health 5 years later and, conversely, WFE at T1 does not explain the perceived health of workers at T2. Thus, the first hypothesis of the study was supported while the second was refuted.

According to Table 2, hypothesis 3, which assumed that job insecurity would interact with WFC to predict its effect on health, was not supported by the data since job insecurity did not prove to be a significant moderator $(b=.08, p=0.16)$, and did not change the negative influence of WFC on the workers' perceived health. On the contrary, concerning hypothesis 4 , which presupposed the moderating effect of job insecurity on the effect of WFE on workers' health, as may also be observed in Table 2, this hypothesis is supported as job insecurity moderated the relationship of WFE at T1 with perceived health at T2 $(b=-0.13, p=0.03)$. Graph 1 shows the interaction and effect of different levels of job insecurity (low insecurity and high insecurity) in the relationship between WFE at T1 with the workers' perceived health at T2. As expected, a buffer effect of job insecurity was

Table 2 Moderation analysis between study variables

\begin{tabular}{lcccc}
\hline Predictor variable & $B$ & $S E$ & $t$ & $p$ \\
\hline DV: Health Perceptions T2 & $R^{2}=.16, p<.001$ (Hypothesis 3) & \\
Constant & 2.06 & .18 & 11.19 & .00 \\
WFC T1 & -.10 & .06 & -1.87 & .05 \\
Insecurity & -.06 & .04 & -1.36 & .17 \\
WFC T1 * Insecurity & .08 & .05 & 1.39 & .16 \\
Gender & .05 & .08 & .59 & .55 \\
Health Perceptions T1 & .33 & .05 & 6.52 & .00 \\
DV: Health Perceptions T2, $R^{2}=.16, p<.001$ (Hypothesis 4$)$ & \\
Constant & 1.99 & .18 & 10.86 & .00 \\
WFE T1 & .06 & .06 & .98 & .33 \\
Insecurity & -.05 & .04 & 1.23 & .22 \\
WFE T1 * Insecurity & -.13 & .06 & -2.20 & .03 \\
Gender & .05 & .08 & .60 & .55 \\
Health Perceptions T1 & .34 & .05 & 6.87 & .00 \\
\hline
\end{tabular}

$\mathrm{N}=373 . D V$ Dependent Variable. Bootstrap sample size $=5000$. All predictor variables are mean-centered; $W F C$ Work-to-family Conflict, WFE Work-to-family enrichment 
observed: in the high insecurity situation, workers' health at T2 did not differ based on low or high WFE at T1; in the low insecurity situation, high WFE at T1, compared to low WFE at $\mathrm{T} 1$, was found to lead to higher perceived health at $\mathrm{T} 2$.

\section{Discussion}

Using a sample of employees from a banking institution analyzed at two points in time, namely in 2012 and 2017, this study aimed to test the influence of the work-family relationship on these workers' perceived health and the moderating role of job insecurity in this relationship. As expected, the results suggest that WFC negatively influenced the perceived health of these workers. More interestingly, job insecurity was found to act as a moderator in the relationship between WFE and perceived health, thus indicating that when there is a higher perception of insecurity, the positive influence of WFE on perceived health ceases to be significant.

Firstly, as expected, WFC was observed to negatively influence perceived health after 5 years. This result is in line with the COR theory (Hobfoll 2002) and the resource loss principle. In particular, WFC triggers stress in individuals owing to a sense of loss of resources (i.e., time, energy, and attention) when trying to combine their work and family roles, which is manifested in negative repercussions for their perceived health. This result reinforces the results of other longitudinal studies that tested this detrimental effect of WFC on well-being and health but with shorter time intervals, namely 6 months (Grant-Vallone and Donaldson 2001), 1 year (Kinnunen et al. 2004), from one to six months (Matthews et al. 2014) and a year and a half (Neto et al. 2016a, b). Thus, this study provides evidence of the detrimental effects of WFC on the health of individuals over a longer period. From Human Resources Management, these results further stress that organizations should take into account that the effect of WFC on the perceived health of workers is felt not only in the short term but also over a long period.

Secondly, and innovatively, the positive effect of WFE on workers' perceived health was found to be mitigated by job insecurity. Thus, it may be said that insecurity prevents the generation of WFE through instrumental and affective means. In other words, even if the work fosters the acquisition of resources leading to the development of positive affect, the fact that there is a threat in this context, such as insecurity, prevents the resources gained from being transferred to the family context. This result is in line with the primacy of resource loss of the COR Theory (Hobfoll 2002), which argues that losses are more potent than gains. In this case, the gain situation understood as the positive relationship established between WFE and health is affected in the face of a threat, namely insecurity. Furthermore, this is also in line with the principle that argues that resources form caravans, that is, resources are aggregated over a certain period so that having one resource means having other resources (Westman et al. 2005). However, as advanced by Westman et al. (2005), just as these resources aggregate, they also tend to disappear together when a threat arises, in this case, job insecurity.

Contrary to expectations, the effect of WFC on workers' health levels was not found to be dependent on the levels of job insecurity they experienced. A possible explanation for this result is that the loss of resources is a very powerful/detrimental process for individuals (primacy of resource loss, Halbesleben et al. 2014) and, in this particular study, the loss of resource process was not only powerful but also extended over a long period (5 years). Therefore, it may be assumed that as the loss of resources is intense and long term, there 
is no other possible factor that can generate more loss, that is, depletion is already so acute that it does not change with another threat/loss, such as insecurity.

\section{Limitations and Suggestions for Future Studies}

This study has some limitations. Firstly, this research only includes the work-family direction and not the family-work direction, and the latter may help to explain the perceived health of individuals over time. Secondly, since the work-family relationship depends not only on the life cycle of individuals but also on demographic and family characteristics that were not analyzed to ensure the anonymity of the participants, it would be interesting to overcome this limitation through the analysis and control of features such as marital status (i.e. single, married, divorced, widowed) and parenthood (i.e. number of children). It would also be important to control aspects of work and, primarily, changes within this context. Considering the changes undergone by the institution, they are likely to influence how the work-family relationship affects the perceived health of employees. Thus, the need for future studies to analyze not only personal and family issues, but also labor issues must be reinforced, as the latter may explain the effects in terms of perceived health. Since the self-assessment and self-report method used may lead to a common method bias, i.e. the measurement error that is compounded by the sociability of respondents who want to provide positive answers (Podsakoff et al. 2003), this may also be considered a limitation in this study. As our results are related to perceived health, new studies could both distinguish between physical and mental health, such as Minnotte and Yucel (2018), but also base the research on data that does not stem solely from self-assessment. However, self-reported data seemed to be the most suitable path to capture employees' perceptions and appraisals of these variables (Fox and Spector 1999) and according to Spector (2006), concerns associated with relying heavily on self-reported data measurements may be excessive. Furthermore, we followed recommendations of Podsakoff et al. (2003) to minimize potential common method biases: confidentiality was guaranteed to avoid participants' editing their answers to make them more consistent and socially desirable; participants were informed that there were no right or wrong answers in the questionnaires; when designing the questionnaire, the independent and dependent variables were placed in separate sections with a different set of instructions to create a psychological separation between the dependent and independent variables.

About future studies, it should be emphasized that in this study job insecurity was analyzed from a quantitative perspective, unlike the study of $\mathrm{Hu}$ et al. (2018) who distinguished between quantitative and qualitative job insecurity, related to the loss of valued features in employment, such as salary and interpersonal relationships (De Witte et al. 2016; Hellgren et al. 1999; Sverke et al. 2002). Future studies could focus on differentiation in this regard, to determine what type of insecurity has more influence on the workfamily relationship and the perceived health of workers, over time.

In terms of age and seniority differences, and since this sample consists mainly of individuals aged between 46 and 55 years, with seniority in the company ranging from 20 to 30 years, it would be interesting to analyze how different generations perceive job insecurity and the work-family relationship. Prior studies have found that younger individuals feel more secure than older individuals, both in terms of job security (Buonocore et al. 2015; Fullerton and Wallace 2007) and financial security (Cheng and Chan 2008), which may be 
due to the ease felt by the younger generations to learn new skills and change careers, thus rendering them less dependent on their current job.

Thus, it is important to maintain this line of research, to continue to explore the stressors and resources that influence the perceived health of today's workers, as now, more than ever, work has a huge influence on all aspects of individuals' lives. In practical terms, it would also be interesting to analyze practices already implemented in companies' and workers' respective perceptions concerning the work-family relationship, job insecurity, and their outcomes.

\section{Practical Implications}

The main result observed in this study is that when job insecurity was perceived, the positive effects of WFE became less significant concerning the perceived health of these workers in the banking sector. Therefore, it is important for the Human Resources Management of companies to ensure that attention is given to these factors and to how they relate to and influence the health of their employees. Thus, not only will they be in a position to identify how to resolve antecedents of job insecurity, but they may also develop tools and practices within the organization to both prevent and reduce this insecurity. Research provided evidence that better communication between managers and employees (Kinnunen et al. 2000), to give more workplace training (Lebert and Antal 2016), social support (Lim 1996) and job control (Bussing 1999) are organizational determinants of job insecurity. Thus, human resource bank departments should take into consideration these evidenced-based practices. Furthermore, in a general manner, this research provides evidence to the Human Resources Management of all sectors that it is increasingly important to maintain a sound work-family balance to avoid a worsening of work-family conflict and enrichment levels, leading us to reflect on how the future health of these workers may be threatened. As such, family-friendly practices (i.e. flexibility policies; care provisions; supportive arrangements; conventional provisions and compensation benefits) and, going beyond, a supportive workfamily culture, where organizations rethink the need to attend their values, norms, and rules to ensure the practices use are recommended (Carvalho and Chambel 2014b).

\section{References}

Allen, T. D., Herst, D. E., Bruck, C. S., \& Sutton, M. (2000). Consequences associated with work-to-family conflict: A review and agenda for future research. Journal of Occupational Health Psychology. https:// doi.org/10.1037/1076-8998.5.2.278.

Armstrong-Stassen, M. (1994). Coping with transition: A study of layoff survivors. Journal of Organizational Behavior. https://doi.org/10.1002/job.4030150705.

Bakker, A. B., Demerouti, E., \& Burke, R. (2009). Workaholism and relationship quality: A spillover-crossover perspective. Journal of Occupational Health Psychology. https://doi.org/10.1037/a0013290.

Bamberger, S. G., Vinding, A. L., Larsen, A., Nielsen, P., Fonager, K., Nielsen, R. N., et al. (2012). Impact of organisational change on mental health: A systematic review. Occupational and Environmental Medicine. https://doi.org/10.1080/09638230500048073.

Batt, R., \& Valcour, P. M. (2003). Human resources practices as predictors of work-family outcomes and employee turnover. Industrial Relations: A Journal of Economy \& Society, 42(2), 189-220. https://doi. org/10.1111/1468-232X.00287.

Broom, D. H., Dsouza, R. M., Strazdins, L., Butterworth, P., Parslow, R., \& Rodgers, B. (2006). The lesser evil: Bad jobs or unemployment? A survey of mid-aged Australians. Social science \& medicine. https ://doi.org/10.1016/j.socscimed.2006.02.003. 
Buonocore, F., Russo, M., \& Ferrara, M. (2015). Work-family conflict and job insecurity: Are workers from different generations experiencing true differences? Community, Work \& Family. https://doi. org/10.1080/13668803.2014.981504.

Burchell, B. (2011). A temporal comparison of the effects of unemployment and job insecurity on wellbeing. Sociological Research Online. https://doi.org/10.5153/sro.2277.

Burgard, S. A., Brand, J. E., \& House, J. S. (2009). Perceived job insecurity and worker health in the United States. Social science \& medicine. https://doi.org/10.1016/j.socscimed.2009.06.029.

Bussing, A. (1999). Can control at work and social support moderate psychological consequences of job insecurity? Results from a quasi-experimental study in the steel industry. European Journal of Work and Organizational Psychology. https://doi.org/10.1080/135943299398339.

Carlson, D. S., Kacmar, K. M., \& Williams, L. J. (2000). Construction and initial validation of a multidimensional measure of work-family conflict. Journal of Vocational Behavior. https://doi. org/10.1006/jvbe.1999.1713.

Carlson, D. S., Kacmar, K. M., Wayne, J. H., \& Grzywacz, J. G. (2006). Measuring the positive side of the work-family interface: Development and validation of a work-family enrichment scale. Journal of Vocational Behavior. https://doi.org/10.1016/j.jvb.2005.02.002.

Carvalho, V. S., \& Chambel, M. J. (2014a). Work-family culture supportive. In A. C. Michalos (Ed.), Encyclopedia of quality of life and well-being research (pp. 7212-7215). Dordrecht: Springer.

Carvalho, V. S., \& Chambel, M. J. (2014b). Work-to-family enrichment and employees' well-being: High performance work system and job characteristics. Social Indicators Research. https://doi. org/10.1007/s11205-013-0475-8.

Carvalho, V. S., \& Chambel, M. J. (2016). Work-to-family enrichment and conflict profiles: Job characteristics and employees' well-being. The Spanish Journal of Psychology. https://doi.org/10.1017/ sjp.2016.63.

Carvalho, V. S., Chambel, M. J., Neto, M., \& Lopes, S. (2018). Does work-family conflict mediate the associations of job characteristics with employees' mental health among men and women? Frontiers in Psychology. https://doi.org/10.3389/fpsyg.2018.00966.

Chambel, M. J., \& Fontinha, R. (2009). Contingencies of contingent employment: Psychological contract, job insecurity and employability of contracted workers. Revista de PsicologíadelTrabajo y de lasOrganizaciones. https://doi.org/10.4321/s1576-59622009000300002.

Cheng, G. H. L., \& Chan, D. K. S. (2008). Who suffers more from job insecurity? A meta-analytic review. Applied Psychology. https://doi.org/10.1111/j.1464-0597.2007.00312.x.

De Witte, H. (1999). Job insecurity and psychological well-being: Review of the literature and exploration of some unresolved issues. European Journal of Work and Organizational Psychology. https:// doi.org/10.1080/135943299398302.

De Witte, H. (2000). Arbeitsethos en job onzekerheid: Meting en gevolgen voor welzijn, tevredenheid en inzet op het werk [Work ethic and job insecurity: Assessment and consequences for well-being, satisfaction and performance at work]. In R. Bouwen, K. De Witte, H. De Witte, \& T. Taillieu (Eds.), Van Groep tot Gemeenschapp [From group to community] Liber Amicorum Prof. Dr. Leo Lagrou (pp. 325-350). Leuven: Garant.

De Witte, H. (2005). Job insecurity: Review of the international literature on definitions, prevalence, antecedents and consequences. SA Journal of Industrial Psychology. https://doi.org/10.4102/sajip .v31i4.200.

De Witte, H., Pienaar, J., \& De Cuyper, N. (2016). Review of 30 years of longitudinal studies on the association between job insecurity and health and well-being: Is there causal evidence? Australian Psychologist. https://doi.org/10.1111/ap.12176.

Demerouti, E., Bakker, A. B., Nachreiner, F., \& Schaufeli, W. B. (2001). The job demands-resources model of burnout. Journal of Applied Psychology. https://doi.org/10.1037/0021-9010.86.3.499.

Diener, E., Inglehart, R., \& Tay, L. (2013). Theory and validity of life satisfaction scales. Social Indicator Research. https://doi.org/10.1007/s11205-012-0076-y.

Edwards, J. R., \& Rothbard, N. P. (2000). Mechanisms linking work and family: Clarifying the relationship between work and family constructs. Academy of Management Review. https://doi. org/10.2307/259269.

Ellonen, N., \& Nätti, J. (2015). Job insecurity and the unemployment rate: Micro-and macro-level predictors of perceived job insecurity among Finnish employees 1984-2008. Economic and Industrial Democracy. https://doi.org/10.1177/0143831x13495720.

Eurofound and the International Labour Office. (2017). Working anytime, anywhere: The effects on the world of work. Geneva: Publications Office of theEuropean Union, Luxembourg, and the International Labour Office. http://eurofound.link/ef1658. 
Ferrera, M., Hemerijck, A., \& Rhodes, M. (2000). The future of social Europe. Recasting work and welfare in the new economy. Oeiras: Celta Editora.

Ferrie, J. E., Westerlund, H., Virtanen, M., Vahtera, J., \& Kivimäki, M. (2008). Flexible labor markets and employee health. SJWEH Supplements, 6, 98-110.

Ford, M. T., Matthews, R. A., Wooldridge, J. D., Mishra, V., Kakar, U. M., \& Strahan, S. R. (2014). How do occupational stressor-strain effects vary with time? A review and meta-analysis of the relevance of time lags in longitudinal studies. Work \& Stress. https://doi.org/10.1080/02678373.2013.877096.

Fox, S., \& Spector, P. E. (1999). A model of work frustration-aggression. Journal of Organizational Behavior. https://doi.org/10.1002/(sici)10991379(199911)20:6<915:aid-job918>3.3.co;2-y.

Frone, M. R. (2000). Work-family conflict and employee psychiatric disorders: The national comorbidity survey. Journal of Applied Psychology. https://doi.org/10.1037/0021-9010.85.6.888.

Frone, M. R., Russell, M., \& Barnes, G. M. (1996). Work-family conflict, gender, and health-related outcomes: A study of employed parents in two community samples. Journal of Occupational Health Psychology. https://doi.org/10.1037/1076-8998.1.1.57.

Frone, M. R., Russell, M., \& Cooper, M. L. (1997). Relation of work-family conflict to health outcomes: A four-year longitudinal study of employed parents. Journal of Occupational and Organizational Psychology. https://doi.org/10.1111/j.2044-8325.1997.tb00652.x.

Fullerton, A. S., \& Wallace, M. (2007). Traversing the flexible turn: US workers' perceptions of job security, 1977-2002. Social Science Research. https://doi.org/10.1016/j.ssresearch.2005.09.005.

Garst, H., Frese, M., \& Molenaar, P. C. M. (2000). The temporal factor of change in stressor-strain relationships: A growth curve model on a longitudinal study in East Germany. Journal of Applied Psychology. https://doi.org/10.1037/0021-9010.85.3.417.

Gaunt, R., \& Benjamin, O. (2007). Job insecurity, stress and gender: The moderating role of gender ideology. Community, Work and Family. https://doi.org/10.1080/13668800701456336.

Geurts, S. A., \& Demerouti, E. (2003). Work/non-work interface: A review of theories and findings. The Handbook of Work and Health Psychology, 2, 279-312.

Giorgi, G., Arcangeli, G., Perminiene, M., Lorini, C., Ariza-Montes, A., Fiz-Perez, J., et al. (2017). Work-related stress in the banking sector: A review of incidence, correlated factors, and major consequences. Frontiers in Psychology, 8, 21-66. https://doi.org/10.3389/fpsyg.2017.02166.

Glavin, P. (2015). Perceived job insecurity and health: Do duration and timing matter? The Sociological Quarterly. https://doi.org/10.1111/tsq.12087.

Goode, W. J. (1960). A theory of role strain. American Sociological Review. https://doi. org/10.2307/2092933.

Grant-Vallone, E. J., \& Donaldson, S. I. (2001). Consequences of work-family conflict on employee well-being over time. Work \& stress. https://doi.org/10.1080/02678370110066544.

Greenhalgh, L., \& Rosenblatt, Z. (1984). Job insecurity: Toward conceptual clarity. Academy of Management Review. https://doi.org/10.2307/258284.

Greenhalgh, L., \& Rosenblatt, Z. (2010). Evolution of research on job insecurity. International Studies of Management and Organization. https://doi.org/10.2753/imo0020-8825400101.

Greenhaus, J. H., \& Beutell, N. J. (1985). Sources of conflict between work and family roles. Academy of Management Review. https://doi.org/10.2307/258214.

Greenhaus, J. H., \& Powel, G. (2006). When work and family are Affilies: A theory of work-family enrichment. Academy of Management Review. https://doi.org/10.5465/amr.2006.19379625.

Grzywacz, J. G. (2000). Work-family spillover and health during midlife: Is managing conflict everything? American Journal of Health Promotion. https://doi.org/10.4278/0890-1171-14.4.236.

Grzywacz, J. G., \& Bass, B. L. (2003). Work, family, and mental health: Testing different models of work-family fit. Journal of Marriage and Family. https://doi.org/10.1111/j.1741-3737.2003.00248 .x.

Grzywacz, J. G., Almeida, D. M., \& McDonald, D. A. (2002). Work-family spillover and daily reports of work and family stress in the adult labor force. Family Relations. https://doi.org/10.111 1/j.1741-3729.2002.00028.x.

Hakanen, J. J., \& Schaufeli, W. B. (2012). Do burnout and work engagement predict depressive symptoms and life satisfaction? A three-wave seven-year prospective study. Journal of Affective Disorders. https://doi.org/10.1016/j.jad.2012.02.043.

Halbesleben, J. R. B., Neveu, J.-P., Paustian-Underdahl, S. C., \& Westman, M. (2014). Getting to the "COR": Understanding the role of resources in conservation of resources theory. Journal of Management. https://doi.org/10.1177/0149206314527130.

Handaja, Y., \& De Witte, H. (2007). Quantitative and qualitative job insecurity: Associations with job satisfaction and mental well-being. Gedrag \& Organisatie, 20(2), 137-159. 
Hantzaroula, P. (2015). The liminal worker: An ethnography of work, unemployment and precariousness in contemporary Greece by manosspyridakis. Journal of Modern Greek Studies. https://doi.org/10.1353/ mgs.2015.0036.

Hayes, A. F. (2012). PROCESS: A versatile computational tool for observed variable mediation, moderation, and conditional process modeling.Retrived from https://www.afhayes.com/public/process2012.pdf

Hellgren, J., Sverke, M., \& Isaksson, K. (1999). A two-dimensional approach to job insecurity: Consequences for employee attitudes and well-being. European Journal of Work and Organization Psychology. https:// doi.org/10.1080/135943299398311.

Hobfoll, S. E. (2002). Social and psychological resources and adaptation. Review of General Psychology, 6(4), 307-324. https://doi.org/10.1037/1089-2680.6.4.307.

Hobfoll, S. E., \& Shirom, A. (2001). Conservation of resources theory: Applications to stress and management in the workplace. In R. T. Golembiewski (Ed.), Handbook of organizational behavior (pp. 57-80). NewYork: Marcel Dekker.

Höge, T., Sora, B., Weber, W. G., Peiró, J. M., \& Caballer, A. (2015). Job insecurity worries about the future, and somatic complaints in two economic and cultural contexts: A study in Spain and Austria. International Journal of Stress Management. https://doi.org/10.1037/a0039164.

Hu, L. T., \& Bentler, P. (1995). Evaluating model fit. In R. H. Hoyle (Ed.), Structural Equation Modeling. Concepts, Issues, and Applications (pp. 76-99). London: Sage.

Hu, S., Jiang, L., Probst, T. M., \& Liu, M. (2018). The relationship between qualitative job insecurity and subjective well-being in Chinese employees: The role of work-family conflict and work centrality. Economic and Industrial Democracy. https://doi.org/10.1177/0143831x18759793.

Kan, D., \& Yu, X. (2016). Occupational stress, work-family conflict and depressive symptoms among Chinese bank employees: The role of psychological capital. International Journal of Environment Research and Public Health. https://doi.org/10.3390/ijerph13010134.

Karasek, R., Brisson, C., Kawakami, N., Houtman, I., Bongers, P., \& Amick, B. (1998). The job content questionnaire (JCQ): An instrument for internationally comparative assessments of psychosocial job characteristics. Journal of Occupational Health Psychology. https://doi.org/10.1037/e366492004-013.

Kinnunen, U., Geurts, S., \& Mauno, S. (2004). Work-to-family conflict and its relationship with satisfaction and well-being: A one-year longitudinal study on gender differences. Work \& Stress. https://doi. org/10.1080/02678370410001682005.

Kinnunen, U., Mauno, S., Nätti, J., \& Happonen, M. (2000). Perceived job insecurity: A longitudinal study among Finish employees. European Journal of Work and Organizational Psychology, 8, 243-260. https:// doi.org/10.1080/135943299398348.

Korkeamäki, O., \& Kyyrä, T. (2014). A distributional analysis of earnings losses of displaced workers in an economic depression and recovery. Oxford Bulletin of Economics and Statistics. https://doi.org/10.1111/ obes. 12028.

Kuroki, M. (2015). Perceptions of job insecurity before, during, and after the Great Recession. WorkingUSA. https://doi.org/10.1111/wusa.12218.

Lebert, F., \& Antal, E. (2016). Reducing employment insecurity: Further training and the role of the family context. SAGE Open. https://doi.org/10.1177/2158244016671769.

Lim, V. K. G. (1996). Job insecurity and its outcomes: Moderating effects of work-based and nonwork-based social support. Human Relations. https://doi.org/10.1177/001872679604900203.

Lochab, A., \& Mor, K. (2013). Traditional to boundaryless career: Redefining career in the 21st Century. Global Journal of Management and Business Studies, 3(5), 485-490.

Matthews, R. A., Wayne, J. H., \& Ford, M. T. (2014). A work-family conflict/subjective well-being process model: A test of competing theories of longitudinal effects. Journal of Applied Psychology. https://doi. org/10.1037/a0036674.

Millsap, R. E. (2011). Statistical approaches to measurement invariance. Abingdon-on-Thames: Routledge/ Taylor \& Francis Group.

Minnotte, K. L., \& Yucel, D. (2018). Work-family conflict, job insecurity, and health outcomes among US workers. Social Indicators Research. https://doi.org/10.1007/s11205-017-1716-z.

Mughal, F., Ahmad, M., Gondal, A. M., Awan, T. M., \& Chaudhry, I. (2010). Repercussions of stressors on employee work-life balance: Analyzing the banking industry of Pakistan. Journal for Global Business Advancement. https://doi.org/10.1504/JGBA.2010.036037.

Neto, F. (1992). The satisfaction with life scale: Psychometrics properties in an adolescent sample. Journal of Youth and Adolescence. https://doi.org/10.1007/bf01536648.

Neto, M., Carvalho, V. S., Chambel, M. J., Manuel, S., Miguel, J. P., \& de Fátima Reis, M. (2016a). Workfamily conflict and employee well-being over time: The loss spiral effect. Journal of Occupational and Environmental Medicine. https://doi.org/10.1097/jom.0000000000000707.

Neto, M., Carvalho, V. S., Chambel, M. J., Manuel, S., Miguel, J. P., \& Reis, M. F. (2016b). Work-family conflict and employee psychological well-being over time: The loss spiral effect. Journal of Occupational and Environmental Medicine. https://doi.org/10.1097/jom.0000000000000707. 
Pearlin, L. I., \& Bierman, A. (2013). Current issues and future directions in research into the stress process. In C. S. Aneshensel, J. C. Phelan, \& A. Bierman (Eds.), Handbook of the sociology of mental health (pp. 325-340). Dordrecht: Springer.

Pförtner, T. K. (2017). Trends in the association between precarious employment and self-rated health in GermanyTimo-KoljaPförtner. European Journal of Public Health. https://doi.org/10.1093/eurpub/ckx18 7.089 .

Podsakoff, P. M., MacKenzie, S. B., Lee, J. Y., \& Podsakoff, N. P. (2003). Common method biases in behavioral research: A critical review of the literature and recommended remedies. Journal of Applied Psychology. https://doi.org/10.1037/0021-9010.88.5.879.

Probst, T. M. (2003). Exploring employee outcomes of organizational restructuring: A Solomon four-group study. Group and Organization Management. https://doi.org/10.1177/1059601102250825.

Rudolph, C. W., Allan, B., Clark, M., Hertel, G., Hirschi, A., Kunze, F., et al. (2020). Pandemics: Implications for research and practice in industrial and organizational psychology. Industrial and Organizational Psychology: Perspectives on Science and Practice. https://doi.org/10.31234/osf.io/k8us2.

Schaufeli, W. B., \& Bakker, A. B. (2004). Job demands, job resources, and their relationship with burnout and engagement: A multi-sample study. Journal of Organizational Behavior: The International Journal of Industrial, Occupational and Organizational Psychology and Behavior. https://doi.org/10.1002/job.248.

Shoss, M. K. (2017). Job insecurity: An integrative review and agenda for future research. Journal of Management. https://doi.org/10.1007/s11846-018-0308-x.

Silva, L. S., \& Navarro, V. L. (2012). Work organization and health of bank employees. Revista Latino-Americana de Enfermagem, 20(2), 226-234. https://doi.org/10.1590/S0104-11692012000200003.

Snorradóttir, Á., Tómasson, K., Vilhjálmsson, R., \& Rafnsdóttir, G. L. (2015). The health and well-being of bankers following downsizing: A comparison of stayers and leavers. Work, Employment and Society. https ://doi.org/10.1177/0950017014563106.

Spector, P. E. (2006). Method variance in organizational research: Truth or urban legend. Organizational Research Methods. https://doi.org/10.1177/1094428105284955.

Sverke, M., Hellgren, J., \& Näswall, K. (2002). No security: A meta-analysis and review of job insecurity and its consequences. Journal of Occupational Health Psychology. https://doi.org/10.1037/1076-8998.7.3.242.

Valadas, C. (2011). New challenges to a changing labour market and welfare state. The Portuguese recent experience. Sociologia Online, 2(4), 9-487.

van de Schoot, R., Lugtig, P., \& Hox, J. (2012). A checklist for testing measurement invariance. European Journal of Developmental Psychology. https://doi.org/10.1080/17405629.2012.686740.

Vieira, J. M., Lopez, F. G., \& Matos, P. M. (2014). Further validation of work-family conflict and work-family enrichment scales among Portuguese working parents. Journal of Career Assessment. https://doi. org/10.1177/1069072713493987.

Voydanoff, P. (2004). The effects of work demands and resources on work-to-family conflict and facilitation. Journal of Marriage and Family. https://doi.org/10.1111/j.1741-3737.2004.00028.x.

Ware, J. E., Davies-Avery, A., \& Donald, C. A. (1978). Conceptualization and measurement of health for adults in the health insurance study: Vol. V, general health perceptions (p. 28). Santa Monica: Rand Corporation.

Westman, M., Hobfoll, S. E., Chen, S., Davidson, O. B., \& Laski, S. (2005). Organizational stress through the lens of conservation of resources (COR) theory. In P. L. Perrewé \& D. C. Ganster (Eds.), Research in occupational stress and well-being: Vol. 4. Exploring interpersonal dynamics (pp. 167-220). Amsterdam: Elsevier Science/JAI Press.

Wikman, A., Marklund, S., \& Alexanderson, K. (2005). Illness, disease, and sickness absence: An empirical test of differences between concepts of ill health. Journal of Epidemiology and Community Health. https://doi. org/10.1136/jech.2004.025346.

Williams, A., Franche, R. L., Ibrahim, S., Mustard, C. A., \& Layton, F. R. (2006). Examining the relationship between work-family spillover and sleep quality. Journal of Occupational Health Psychology. https://doi. org/10.1037/1076-8998.11.1.27.

World Health Organization [WHO]. (2015). The European mental health action plan 2013-2020. Geneva: World Health Organization.

Publisher's Note Springer Nature remains neutral with regard to jurisdictional claims in published maps and institutional affiliations. 